\title{
Hodepine og hengende øyelokk
}
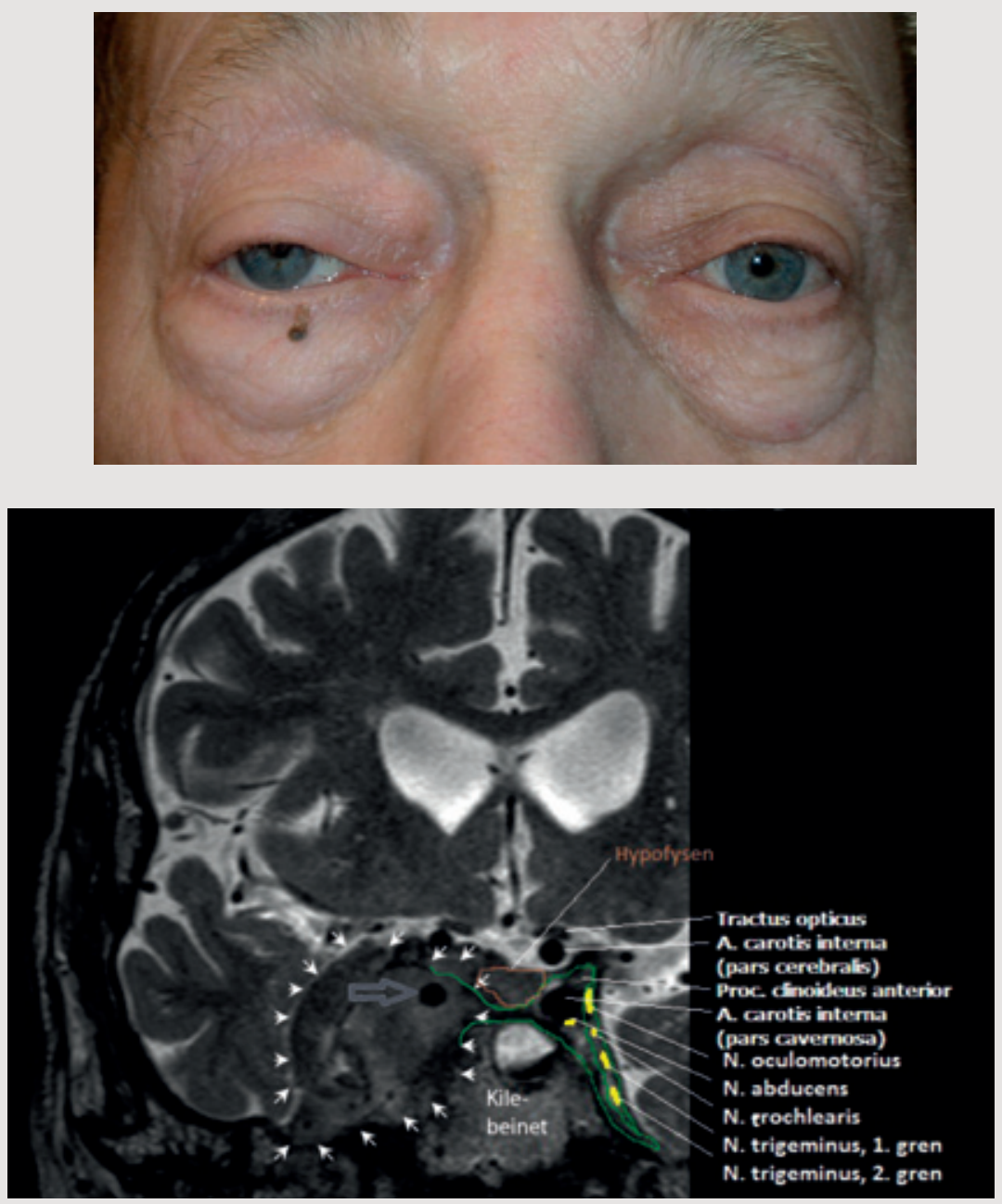

En mann i 70-årene ble utredet for kronisk høyresidig hodepine. Bortsett fra et hengende øyelokk og lett anisokori, typisk for Horners syndrom, ble det ikke påvist nevrologiske utfall. Cerebral MR avdekket en tumor (pilhoder) i høyre sinus cavernosus.

Sinus cavernosus (grønt omriss av venstre side) utgjør et venøst rom dannet av durale folder på hver sin side av kilebeinet og sella turcica, som ligger på øvre flate av dette. Et horisontalt segment av a. carotis interna med dets sympatiske pleksus i adventitia følges tett av $n$. abducens gjennom denne kanalen på hver sin side av hypofysen, der de bades $i$ blod. I en normal sinus fremstår den laterale veggen som konkav. I den ligger flere hjernenerver (n. oculomotorius, n. trochlearis $\operatorname{og} \mathrm{n}$. trigeminus).

Hos denne pasienten er høyre a. carotis interna (pars cavernosa) konstringert (pil) og laterale vegg av sinus cavernosus kon- veks. Hodepine samtidig med Horners syndrom indikerer at 3 . ordens okulosympatiske nevroner (i praksis de fibrene som forløper langs a. carotis interna) er affisert. Kombinert med parese i n. oculomotorius, $n$. trochlearis, n. trigeminus og spesielt i n. abducens skal det alltid gi mistanke om lesjon i sinus cavernosus. Tumors størrelse tatt i betraktning er det påfallende at det kun foreligger et Horners syndrom hos denne pasienten.

Pasienten har gitt samtykke til at artikkelen blir publisert.

\section{Karl Bjørnar Alstadhaug}

karl.bjornar.alstadhaug@nordlandssykehuset.no Nevrologisk avdeling Nordlandssykehuset

\section{Roar Kloster}

Nevrokirurgisk avdeling

Universitetssykehuset Nord-Norge

Karl Bjørnar Alstadhaug (f. 1972) er spesialist i nevrologi, overlege og førsteamanuensis. Ingen oppgitte interessekonflikter.

Roar Kloster (f. 1960) er spesialist i nevrokirurgi og i øyesykdommer.

Ingen oppgitte interessekonflikter. 